IRA-International Journal of Management \& Social Sciences

ISSN 2455-2267; Vol.03, Issue 03 (2016)

Institute of Research Advances

http://research-advances.org/index.php/RAJMSS

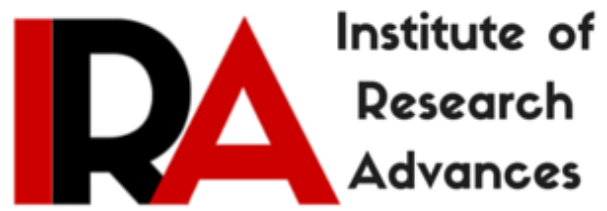

\title{
Are Fines An Effective Sanction?
}

\section{Guiller P. Pendon}

West Visayas State University- Janiuay Campus

Cabesa Jose D. Brana Street

Janiuay, Iloilo, Philippines.

DOI: http://dx.doi.org/10.21013/jmss.v3.n3.p2

How to cite this paper:

Pendon, G. (2016). Are Fines An Effective Sanction?. IRA-International Journal of

Management \& Social Sciences (ISSN 2455-2267), 3(3).

doi:http://dx.doi.org/10.21013/jmss.v3.n3.p2

(C) Institute of Research Advances

\section{(cc) EY-NC}

This works is licensed under a Creative Commons Attribution-Non Commercial 4.0 International License subject to proper citation to the publication source of the work.

Disclaimer: The scholarly papers as reviewed and published by the Institute of Research Advances (IRA) are the views and opinions of their respective authors and are not the views or opinions of the IRA. The IRA disclaims of any harm or loss caused due to the published content to any party. 


\begin{abstract}
The study explored the perception of fourth year students on the implementation of monetary sanctions as fines for non-attendance in school activities. The study examined the extent in which fines were perceived, whether or not this fines would be reimposed or not in the future. The study employed descriptive and qualitative designs. Descriptive data was obtained through a questionnaire checklist. There were 12 respondents who were interviewed and their responses were summarized and interpreted accordingly. The findings revealed that the respondents have poor perceptions on the implementation of fines in the form of monetary sanctions while the qualitative data seems to prove that respondents considered fines as an effective sanction to improve students' attendance in school activities.
\end{abstract}

Keywords: Fines, Monetary Sanctions, School Activities

All learners in a school benefit when behavior is good. High standards of behavior are important in helping learners to feel safe and learn well, and parents play a key part in this. In fact, government advises schools to focus on promoting positive behavior, helping to build self-discipline and encouraging respect for others. But schools also need sanctions to deter learners from misbehaving (Kaplow, 1990).

Most schools have published an escalating system of sanctions ranging from removal from classes, loss of privileges, reporting to senior staff, contact with parents/guardians, being placed on 'report' and behavior 'contracts', through to temporary exclusions and, ultimately, expulsion (Falk, 2005)

Kaplow (1990) mentioned that schools should review their disciplinary measures to promote positive behavior policies regularly and publicize them to parents, staff and students. The precise content of a school's policy is a matter for each school to determine in consultation with parents. Discipline or positive behavior policies should include a code of discipline for students. Rules on conduct can apply before and after school, as well as during the school day. They can set expectations on how learners will behave at any time and situation.

The primary purpose for the Code of Discipline in any school setting is to respond to incidents of non-academic misconduct in a way that is developmentally sound and which creates an environment in which all members of the academic community can live, work, and learn together. The Code is designed to provide educational guidance to those wishing to develop into good citizens and, at the same time, to respond appropriately to aberrant behavior that damages the living or present learning environment on campus (Altman, 2008).

Imposing fine in schools was a popular form of discipline until the 1970's when most schools adopted the "no corporal punishment and non-monetary policies", however, 
it is starting to make a comeback. In some school it never lost its popularity and is still very much a policy today (Coleman, 1990).

Coleman (1990), further discussed that it can be a very tough and emotionally charged subject because many students do not feel comfortable with anyone imposing fines but some are fine with it. Some parents feel that fines through monetary sanctions are never appropriate while others feel that it is important that the school system has this option to reign for unruly students.

Unlike society, the University is a voluntary association of scholars which demands and deserve a positive and special learning environment, as well as a special approach for enforcing the academic community's standards. The University is a community dedicated to the principles of free expression in which diverse views are encouraged and embraced. Opinions that may be unpopular and/or contrary to the university's values and objectives, but do not otherwise violate policy, will not be sanctioned (Balton, 2000).

The theoretical basis for this discipline code can be derived from the law of God as summarized in Matthew 22:37-40, the Christian law of love. Christians must learn to love God above all and their neighbors as themselves. Yet such love is often feeble, fragmentary, and deficient. The Christian law of love cannot be stated in narrow, legalistic terms, for it can never be fulfilled simply by the observance of a set of rules and regulations. Consequently, this code does not seek to develop a detailed and exhaustive summary of what a student may or may not do. On the other hand, it is a sound Biblical principle that everything must be done in good order; hence, this code does contain, in addition to positive Christian principles of behavior, a list of proscribed conduct and a well-defined procedure for the implementation of the code (Ellingsen, 2008).

The West Visayas State University-Janiuay Campus through student organizations strives to maximize students' involvement and participation in campus activities. The campus has centralized, comprehensive leadership-training programs manifested in the series of school activities. However, last school years 2012-2014 a fine for students' absences through a monetary sanctions were implemented. The decision was carried out through a joint resolutions from different student organizations to implement monetary sanction for every absences incurred of students during the conduct of school activities. With the intention to consider the students free and willful participation to campus activities in the absence of fines the said implementation of monetary sanction lasted only for two (2) years.

Since a study on the effectiveness of the implementation of monetary sanctions was understudies, it is deemed necessary and interesting to look into the perception of students on the implementation of monetary sanctions for absences incurred during the student activities, thus, this study was made.

This study aimed at ascertaining the students' perception the implementation of monetary sanctions.

Specifically, this study sought answers to the following questions

1. What is the level of perception of fourth year students as to the implementation of monetary sanctions when taken as a whole and classified as to sex and course? 
2. What are the factors influencing the respondents to view fines as sanctions?

3. What are the views of the respondents on the effectiveness on the implementation of monetary sanctions as fines for absences in school activities?

\section{Methodology}

This study utilized the descriptive design to collect, analyze and classify data on perceptions of fourth year students on the implementation of monetary sanctions.

As initial step, the researcher identified the respondents during SY 2015-2016. Identification of respondents was based on sex and course. The fourth year students were chosen because they were part of the implementation of monetary sanctions when they were first year and second year students then. Total enumeration was utilized in ascertaining the answers in the twenty-four items questionnaire checklist on the implementation of monetary sanctions.

The researchers constructed a rating scale designed to determine the level of perception of fourth year students to the implementation of monetary sanctions, aside from that, representatives among respondents were also asked through focused group discussion (FGD) if they consider such fine as an effective sanction. It was during the first semester SY 2015-2016 that the respondents were asked about their perceptions. There were two (2) engagement questions, five (5) exploratory questions and one (1) exit question utilized during the conduct of FGD.

There were 12 participants in the Focused Group Discussion (FGD). Six (6) of them were males and six (6) were females. They were purposively chosen. The participants represented the six (6) degree courses. Prior to the determination of participants they were first introduced to the topic and the consent was solicited and it was freely given by the respondents. Confidentiality of their person was assured.

The researcher gathered the accomplished instruments as soon as the respondents finish answering them and note down the responses of the respondents during focused group discussions.

The data obtained from the research questionnaire were tallied, computer processed, analyzed and interpreted. The qualitative data was compiled, analyzed and synthesized on this paper.

\section{Respondents}

Table 1

Profile of the Respondents as to Sex and Course

\begin{tabular}{|lll|}
\hline Categories & $\mathrm{F}$ & $\%$ \\
$\begin{array}{l}\text { Entire group } \\
\text { Sex }\end{array}$ & 313 & 100 \\
$\quad$ Male & & \\
$\quad$ Female & 106 & 33.87 \\
$\quad$ & 207 & 66.13 \\
\hline
\end{tabular}




\begin{tabular}{|lll|}
\hline Course & & \\
Bachelor in Secondary Education & 67 & 21.41 \\
Bachelor in Elementary Education & 118 & 37.70 \\
$\begin{array}{l}\text { Bachelor in Hotel \& Restaurant Services } \\
\text { Technology }\end{array}$ & 38 & 12.14 \\
$\begin{array}{l}\text { Bachelor of Science in Information Technology } \\
\text { Bachelor of Science in Industrial Technology }\end{array}$ & 44 & 14.05 \\
Bachelor in Caregiving Management & 36 & 11.50 \\
\hline
\end{tabular}

\section{Research Instrument}

The data-gathering instrument that was used in the study was a 24-item checklist on the perception of students' in the implementation of monetary sanctions.

There were five levels to be determined: Poor, Fair, Satisfactory, Very Satisfactory and Excellent.

"Poor" means that the respondents consider fines in the form of monetary sanctions as not effective.

"Fair" means that the respondents consider fines in the form of monetary sanctions as less effective.

"Satisfactory" means that the respondents consider fines in the form of monetary sanctions as somehow effective.

"Very Satisfactory" means that the respondents consider fines in the form of monetary sanctions as effective.

"Extremely Aware" means that the respondents consider fines in the form of monetary sanctions as very effective.

In determining the results a scale was used:

$$
\begin{gathered}
\text { Scale of Mean } \\
4.51-5.00 \\
3.51-4.50 \\
2.51-3.50 \\
1.51-2.50 \\
1.0-1.50
\end{gathered}
$$

Description

Excellent Very satisfactory Satisfactory Fair Poor

\section{Findings}

Table 2 showed that when the respondents were categorized as to sex and course they have considered implementation of monetary sanctions as fines as "not effective". It was believed that given the right tools, students will thrive in taking charge of their own development, but to help them do this, we need to reassess our role as higher education providers. We should not just provide the opportunities for students to achieve 
good academic results but actively promote the benefits of a wider curriculum to students. After all, university should be seen as a transformative experience through which students can prepare themselves to succeed in the many and varied roles they will undertake in future life (Trevino, 2002).

Table 2. Means and Standard Deviations of Over-all Scores on the Perceptions of students in the Implementation of Monetary Sanctions when Classified as to Sex and Course.

\begin{tabular}{|c|c|c|c|}
\hline Categories & Mean & $\mathrm{SD}$ & Description \\
\hline Entire group & 1.0735 & .2613 & Poor \\
\hline \multicolumn{4}{|l|}{ Sex } \\
\hline Male & 1.0755 & .2654 & Poor \\
\hline Female & 1.0725 & .2598 & Poor \\
\hline \multicolumn{4}{|l|}{ Course } \\
\hline Bachelor in Secondary Education & 1.0896 & .2876 & Poor \\
\hline Bachelor in Elementary Education & 1.0763 & .2666 & Poor \\
\hline $\begin{array}{l}\text { Bachelor in Hotel \& Restaurant Services } \\
\text { Technology }\end{array}$ & 1.0789 & .2738 & Poor \\
\hline Bachelor of Science in Information Technology & 1.0682 & .2550 & Poor \\
\hline Bachelor of Science in Industrial Technology & 1.0556 & .2323 & Poor \\
\hline Bachelor in Caregiving Management & 1.0000 & .0000 & Poor \\
\hline
\end{tabular}

Astin (1993), stated that having an active college social life by participating in college student organizations could influence how one perceives his or her own college experience. He added that students with more opportunities to involve in the overall student life of the institution could have more student-to-student interactions. Consequently, student interactions were found to cultivate a more active social life in college.

Pascarilla (2001), found out that when thinking in retrospect, college graduates perceived their extracurricular involvement as having substantial impact on the development of interpersonal and leadership skills important to general occupational success as influenced by fear of fines, motivations from peers and desire to enhance interpersonal and leadership skills, allowing students to explore their goals and to identify steps to achieve such goals.

Table 3 revealed the four factors during the interview when the selected respondents were asked as to the underlying reasons why they have to attend school activities and trying-out to avid the payment of monetary sanctions. It showed that economic factors were ranked first and academic factor was the least.

This can be inferred in the idea of Baker (2001) that participation of students in various activities can be considered as meta-construct that includes behavioral, emotional and cognitive engagement. What makes participation unique is on how it can draw on the involvement in academic, social and extra-curricular activities and is considered crucial for improving positive academic outcomes. 
Table 3. Factors influencing Respondents' View of Monetary Sanctions as Fines

\section{Factors affecting Respondents' View of Monetary Sanctions as Fines $\quad$ F Rank}

Personal Factor (it's a matter of choice)

Academic Factor (it's all about the grades)

Social Factor (it's about social responsibility)

Economic Factor (it's the money that counts)

$\begin{array}{ll}3 & 2 \\ 1 & 4 \\ 2 & 3 \\ 5 & 1\end{array}$

In other words the school should talk to the student, identifying the problem and explaining how the important the attendance to school activity is. The school should also explain the effect of being absent. The student should be punished only if he or she cannot give a reasonable explanation. If the misbehavior is repeated, or there are a number of incidents, the school may keep a record of these (Burton, 2001).

Table 4 showed the different views of the respondents on the implementation of monetary sanction as fines during absences in every school activity.

Willms, (2000), stated that most students participated in academic and nonacademic activities at school even no fines imposed on the attendance simply because most of them wanted to develop sense of belonging with their friends, have good relations with teachers and other students, and identify with and value schooling outcomes.

Table 4. Views of Respondents on the Implementation of Monetary Sanctions as Fines

\begin{tabular}{|c|c|c|}
\hline Views about Monetary Sanctions & $\mathbf{F}$ & Rank \\
\hline $\begin{array}{l}\text { 1. Monetary sanctions forced a student to attend a school activity } \\
\text { and deprived one's opportunity to find partime jobs after school }\end{array}$ & 2 & 6 \\
\hline $\begin{array}{l}\text { 2. Monetary sanction cannot forcibly require a student to attend } \\
\text { school activities, in fact, it is a personal choice }\end{array}$ & 2 & 6 \\
\hline $\begin{array}{l}\text { 3. Monetary sanctions has increased students' attendance to } \\
\text { whatever school activities compared to the time when monetary } \\
\text { sanctions was stopped }\end{array}$ & 1 & 8 \\
\hline $\begin{array}{l}\text { 4. Monetary sanctions served as a motivating factor while it } \\
\text { unintentionally developed social well-being }\end{array}$ & 5 & 2 \\
\hline $\begin{array}{l}\text { 5. To excuse oneself from monetary sanctions is just all about } \\
\text { signing an attendance sheet }\end{array}$ & 2 & 6 \\
\hline 6. Monetary sanction is a money "money-making thing" & 3 & 4 \\
\hline $\begin{array}{l}\text { 7. Monetary sanctions is a burden to those who have limited } \\
\text { allowance }\end{array}$ & 5 & 2 \\
\hline $\begin{array}{l}\text { 8. Monetary sanctions is "an easy-thing" for those who have money, } \\
\text { thus, it won't be fair }\end{array}$ & 5 & 2 \\
\hline
\end{tabular}

During the conduct of Focused Group Discussions (FGD), the participants were asked to freely and openly discuss their perceptions and ideas on various questions raised. The identity of the respondents was held confidential. The responses were properly noted, summarized and translated on this paper. 


\section{Engagement questions}

1. Do you regularly attend to campus activities?

On this question 10 of the respondents said that they were regularly attending whatever school activities being held in the campus. However, two of them said that "kung waay sanction sir indi takon mag attend kay yadi pa magbyahe ako trisikad para may balon adlaw-adlaw" in other words he was only attending the school activity because there was a sanction being implemented, if not he would rather spend his time driving a "trisikad" to earn for his daily allowance.

The other respondent said that "depende sa activity kung manami eh". In short her presence during the school activity was dependent on the worthiness of the activity being conducted.

2. What do you notice to other students' attendance during campus activities before and now?

On this question seven of the respondents said that whatever activities held in the campus before, the attendance was almost perfect while now students were becoming choosy of the campus activities that they would like to attend.

One respondent did not see any difference in the attendance of students before and now and said that "daw waay man nagbag-o sa attendance sang mga estudyante kay pirme man gagirinutok" Nothing compares with the students' attendance because the venue was always overcrowded. The other three respondents just agreed to the idea.

However one respondent said "mas duro gaattend sang una nga may monetary sanction kay nahadlok sila mapinahan kumparar subong nga makapirma lang attendance okay na"

To translate, the respondent said that in the past many attended the school activities because of the fear to pay a sanction compared in the present that it is already fine once a student have signed the attendance.

\section{Exploratory questions}

3. What in particular influenced you to attend or not to attend the campus activities?

Five respondents said it was the motivation, excitement and desire to get along with others in particular influences them to be in school activities. To quote one of the respondents' idea "Excited kmi sir mag join kag makisalamuha sa iban".

One respondent said that it's the idea that if they will be absent there will be fines and their clearances might not be signed. To quote "basi may fine sir kag indi tamon kapapirma klerans". This idea was supported by other five respondents.

Another respondent said that he was influenced by his friends and classmates to be around.

4. What are the pros and cons of imposing fines through monetary sanctions for those who are absent in the conduct of campus activities? 
Encouraging maximum participation in campus activities, becoming law-abiders, developing sense of discipline, helping raise funds for campus projects and high levels of social interaction among students despite of differences are the pros of imposing fines through monetary sanctions were given by the respondents.

However, as to cons, the respondents said that "kung my fine daw ginapwersa gid kmi mag attend"; " waay na gani kmi balon mabayad pa kmi sanction", "indi manami kay taga-absent mo mabayd kaw kag kung may kwarta timu te bayd lang kaw?...unfair man", "daw pangwarta lang eh" and "gaaattend lang students kay nahadlok sa fine".

To translate the aforementioned responses the cons are as follows: "It's just like forcing us to attend though we don't like", "we have limited allowance but then we'll be paying as well for sanction", "it's not well if you always have to pay if you're absent, what if you have money? You'll just have to pay?...it is not fair, "it's just like money making thing" and "students just attended the activities because of fear of fines.

5. How do you feel when fines through monetary sanctions are being collected?

One respondent said that "I pity those student who has no money, yet, they'll be required to pay their monetary sanctions... and she added " they can hardly have an allowance because they were housemaids, farm helpers, market vendors, drivers and others...so what will happen to them if they'll be required to pay a sanction...I feel very sorry for them" This idea was supported by another respondent, to quote, " singkwenta malang ang ana ka iban allowance sa isa ka adlaw tapos ang sanction kung absent kaw sa isa ka adlaw kwarenta... panu dlang hay? Others have P50.00 allowance in a day then if they have sanction they'll pay P40.00 in a day as well, how will they survive?

6. Do you consider fines through monetary sanctions effective or not effective in maximizing students' attendance in school activities?

All respondents said that imposing fines through monetary sanctions was an effective scheme to maximize students' attendance in school activities, since, majority of the students attended once there was a sanction.

\section{Exit questions}

7. Is there anything else would you like to say about imposing fines through monetary sanctions for those students who failed to attend school activities?

When the this last question was asked one respondent quickly answered "We don't need a monetary sanction, it all depends on how the school authority would encourage and motivate the students to attend the school activities, we have already noticed that even though sanction was no longer imposed but still majority, if not all, students were present every now and then when school activities have been conducted.

Another respondent said "may sanction o wala depende na sa rules of discipline sang school". To translate "If there will be sanction or none, still it all depends on the disciplinary measures of the school" 


\section{Conclusions and Recommendations}

The days of the cane are long gone. Increasingly, schools prefer to reward good behavior rather than punish misdemeanors. But most teachers still find that sanctions are necessary to maintain discipline and motivation. So which deterrents work best? Is it acceptable to make children sit in silence and write lines, or should punishments always be constructive? And if schools are going to offer incentives, how far should they go? With some pupils receiving cinema tickets or driving lessons just for turning up regularly, critics argue that rewards systems are getting out of hand.

Good attendance shows potential graduates that your students is reliable. Research suggests that children who attend school activities regularly could also be at less risk of getting involved in antisocial behavior or crime.

To consider the trend of schools forcing students to pay fines for non-attendance to school activities is counterproductive, and the fines often hit students who least can afford them.

The practice is an idiotic attempt to change students' behavior by making them pay. We keep hearing examples of this kind from around the country. Anyway imposing fines may not guarantee that result wanted is being attained.

The school activities that encourage attendance from students help the students to develop social skills, improve academic performance, and help them build strong supportive relationships with other students and school personnel. Students at their young age can benefit especially from the social skills development and improved academic skills. This leads to improved conflict management and better school attendance. The students who continue to participate in school activities even without sanctions imposed are more likely to be engaged in school and attentive in class and less likely to be involved in violent behavior at school.

Participation without sanction in school activities continues to be a benefit for students' right. Students will become optimistic for the future and have more interest in school than peers who are unsupervised after school.

Once a fine is given it must be proportionate. In determining whether a fine is reasonable in all the circumstances and that account must be taken of the student's age, any special educational needs or disability they may have, and any religious requirements affecting them their attendance in school activities, their economic status and academic and non-academic backgrounds. It is recommended that:

Schools can further goals of social control by socializing students into behaving in socially acceptable ways. By means of social control, students are taught the boundaries of acceptable behavior. Informal social control is exercised by a society without explicitly stating these rules, and is expressed through customs, norms, and mores.

It is vital that the attendance in school activities policy is clear, that it is well understood by staff, parents and students, and that it is consistently applied. In developing 
this policy, it must reflect a consistent approach to behavior management strong school leadership, classroom management, rewards and sanctions; behavior strategies and the teaching of good behavior and student development and support.

Teachers have statutory authority to discipline students whose attendance in school activities is unacceptable and help students follow a reasonable policy on students' attendance. Schools through Office of Student Affairs can also discipline students in certain circumstances.

Schools should have in place a range of options and rewards to reinforce and praise good behavior, and clear non-monetary sanctions for those who do not comply with the school's attendance policy. These will be proportionate and fair responses that may vary according the types of students.

\section{References}

Altman, S. (2008) “ Do the Reciprocal Trust Less?” Economics Letters, 99,pp 454-457

Astin, A.W. (1993). What matters in college? Four-critical years revisited. San Francisco: Jossey-Bass.

Baker, M. L., Sigmon, J. N. and Nugent, M. E. (2001). Truancy reduction: Keeping students in schools. Rockville MD: Juvenile Justice Clearinghouse.

Bolton, G, (2000) "ERC: A Theory of equity, Reciprocity, and Competition", American Economic Review, 90 (1), pp. 166-93

Burton, M.D. (2001). Identifying potential participants for college extracurricular activities. College Student Journal.

Coleman, J. (1990) "Foundations of Social Theory", Cambridge, MA: Harvard University Press

Ellingsen, T. (2008) "Anticipated Verbal Feedback Induces pro-Social Behavior", Evolution and Human Behavior, 29, pp. 100-105

Falk, A. (2005). "Driving Forces behind Informal Sanctions", Econometrica, 7(6).pp 2017-30

Kaplow, L. (1990), "A note on the Optimal use of Non-monetary Sanctions" 42 Journal of Public Economics, 245-247

Pascarilla, E. et al. (2001). How college affects students. San Francisco: Jossey-Bass. Trevino, J. (2002). Participation in ethnic/racial student organizations. University of California, Los Angeles: Unpublished doctoral dissertation.

Willms, J.D. (2000). Student engagement at school a sense of belonging and participation.

Organization for Economic Co-operation and Development (OECD) Journal. 